\title{
Ranitidine compared with cimetidine in the short-term healing of duodenal ulcer
}

\author{
FRANK I. LEE \\ M.B., F.R.C.P. \\ J. D. FIELDING \\ M.B., M.R.C.P. \\ F. T. COSTEllo \\ B.Sc., M.B., M.R.C.P. \\ Department of Gastroenterology, Victoria Hospital, Blackpool, Lancashire
}

\begin{abstract}
Summary
The efficacy of ranitidine (150 $\mathrm{mg}$ twice daily) and cimetidine $(200 \mathrm{mg}$ three times daily and $400 \mathrm{mg}$ at night) in the short-term healing of duodenal ulcer has been assessed in a randomized controlled trial involving 106 patients. There were 3 drop-outs. Fortytwo out of 53 patients (79\%) treated with ranitidine had healed ulcers at 4 weeks compared with 37 out of 50 treated with cimetidine $(74 \%)$. This difference is not significant. At 8 weeks the healing rate for ranitidine (98\%) was significantly greater than that for cimetidine $(86 \%)(P<0.05)$. There was no significant difference in healing rates between men and women and between smokers and non-smokers. Side effects were not a problem with either drug. There were no differences of clinical significance between laboratory values in the two treatment groups, although a minor increase in mean creatinine levels occurred in the cimetidine-treated group.
\end{abstract}

KEY WORDS: ranitidine, cimetidine, duodenal ulcer.

\section{Introduction}

Ranitidine, the second $\mathrm{H}_{2}$ receptor antagonist to be introduced into clinical practice in the United Kingdom, has been shown to have a marked inhibitory effect on gastric acid secretion, greater than that of cimetidine. We report a trial comparing ranitidine and cimetidine in the short-term healing of duodenal ulceration.

\section{Patients and methods}

Patients with endoscopically proven duodenal ulcer have been admitted to a single-centre randomized single-blind (endoscopist) trial of treatment with ranitidine $150 \mathrm{mg}$ b.d. or cimetidine $200 \mathrm{mg}$ t.d.s. and $400 \mathrm{mg}$ at night. The trial was approved by the Ethical Committee of Victoria Hospital, Blackpool, according to the Declaration of Helsinki. The pur- pose of the study was explained to the patients. Nonis of the patients had received ulcer healing agents ipo the previous month. Patients were excluded if the $5^{\circ}$ had gastric ulceration, previous gastric surgeryg pyloric stenosis, recent treatment with 'ulcerogenic drugs, recent perforation, concurrent serious disease and if they were pregnant, liable to conceive during the trial or if they were breast-feeding. After an initias clinical, haematological and biochemical assessmen endoscopy was carried out to confirm the presencefof duodenal ulceration and informed consent obtainecer Consecutive patients were admitted according te previously determined schedule. Supplies of antaet (Rennies-Nicholas Laboratories) and the treatment drug were issued. At 2 and 4 weeks, the baseline assessments were repeated and a count of th\% treatment tablets made to assist in determining compliance. Healing, defined as complete epitheliali zation of the ulcer, was assessed by endoscopy at $\$$ weeks. Endoscopy was repeated at 8 weeks if the ulcer was unhealed at 4 weeks. Distribution and. counting of treatment tablets were undertaken by staff in the Department of Gastroenterology, Victoria Hospital, Blackpool, who had no communication with the clinical assessor or the endoscopist.

\section{Statistical methods}

(1) Ulcer healing has been assessed using the two sided Mantel-Haenszel chi-square test without conti nuity correction (Snedecor and Cochran, 1967). N

In view of the difference in length of dyspeption history between the two treatment groups, an analy sis of the efficacy data was carried out after stratifica $-\overline{-}$ tion into two groups with a relative short (under years) or long (over 5 years) history.

(2) Data for selected laboratory investigations were analysed for differences between the mean or geo:metric mean values in the treatment groups at the pretreatment and 28-day visits. The calculation of 
TABLE 1. Background data for patients completing the trial

\begin{tabular}{lcc}
\hline & Ranitidine & Cimetidine \\
\hline $\begin{array}{l}\text { No. completed trial } \\
\text { Sex (M/F) }\end{array}$ & 53 & 50 \\
$\begin{array}{l}\text { Age (yrs): } \\
\text { mean (range) }\end{array}$ & $39 / 14$ & $39 / 11$ \\
$\begin{array}{l}\text { Weight (kg): } \\
\text { mean } \pm \text { s.d. }\end{array}$ & $48(19-76)$ & $48(25-76)$ \\
$\begin{array}{l}\text { Smokers/non-smokers } \\
\text { Duration of }\end{array}$ & $71 \pm 12$ & $69 \pm 12$ \\
$\quad$ dyspepsia (yrs): & $39 / 14$ & $31 / 19$ \\
$\quad$ mean (range) & & \\
$\begin{array}{l}\text { Duration of current } \\
\text { episode (weeks): } \\
\text { mean (range) }\end{array}$ & $5.7(0-30)$ & $13(0-31)$ \\
\hline
\end{tabular}

Note: there is a difference in the duration of dyspepsia between the two groups.

95\% confidence limits was based on the $t$-distribution if within-treatment variances were similar, and by means of an extension to Satterthwaite's rule for variances which were significantly different (Satterthwaite, 1946).

\section{Results}

Between January and November 1981, 106 patients were entered in the trial. There were 3 dropouts, 2 associated with failure of compliance, and one man who complained of a light-headed sensation which he attributed to the treatment agent. All 3 had received cimetidine. One hundred and three patients completed the trial, 53 ( 39 men and 14 women) received ranitidine and 50 (39 men and 11 women) received cimetidine. The background data of patients completing the trial are shown in Table 1. The drug groups were evenly matched apart from the duration of dyspepsia which was on average 5-7 years in the ranitidine group and 13 years in the cimetidine group.

After 4 weeks, $42(79 \%)$ patients on ranitidine and $37(74 \%)$ on cimetidine had healed. This difference is not significant. After 8 weeks, 52 (98\%) on ranitidine and $43(86 \%)$ on cimetidine had healed. This difference is statistically significant $(P<0.05)$. In view of the difference in the duration of the dyspeptic history between the ranitidine- and cimetidine-treated groups, healing rates were compared according to the length of history. There was no difference between groups with histories of less than or greater than 5 years (Table 2). In addition, there were no significant differences between smokers and non-smokers (Table 3) and between men and women, although the healing rate for men on ranitidine at 8 weeks (100\%) was significantly better than those on cimetidine $(87 \%)(P<0.05)$ (Table 4).

TABLE 3. Healing rates for smokers and non-smokers on ranitidine and cimetidine

\begin{tabular}{llcc}
\hline & Treatment & Healed 4 weeks & Healed 8 weeks \\
\hline $\begin{array}{llll}\text { Smokers } \\
n=39\end{array}$ & Ranitidine & $31(79 \%)$ & $38(97 \%)$ \\
$n=31$ & Cimetidine & $22(71 \%)$ & $27(87 \%)$ \\
& Total & $53(75 \%)$ & $65(93 \%)$ \\
Non-smokers & & & \\
$n=14$ & Ranitidine & $11(79 \%)$ & $14(100 \%)$ \\
$n=19$ & Cimetidine & $15(79 \%)$ & $16(84 \%)$ \\
& Total & $19(78 \%)$ & $30(90 \%)$ \\
\hline
\end{tabular}

Differences between smokers and non-smokers are not statistically significant.

TABLE 4. Healing rates for men and women on ranitidine and cimetidine

\begin{tabular}{llcr}
\hline & Treatment & Healed 4 weeks & Healed 8 weeks \\
\hline Men & & & \\
$n=39$ & Ranitidine & $32(82 \%)$ & $39(100 \%)$ \\
$n=39$ & Cimetidine & $28(72 \%)$ & $34(87 \%)$ \\
& Total & $60(77 \%)$ & $73(94 \%)$ \\
Women & & & \\
$n=14$ & Ranitidine & $10(71 \%)$ & $13(93 \%)$ \\
$n=11$ & Cimetidine & $9(82 \%)$ & $9(82 \%)$ \\
& Total & $19(76 \%)$ & $22(88 \%)$ \\
\hline
\end{tabular}

Differences between men and women are not significant. The healing rate for men on ranitidine $(100 \%)$ at 8 weeks is significantly different from the rate on cimetidine $(87 \%)(P<0.05)$.

\section{Unwanted effects}

These were minimal. One patient declined to continue treatment with cimetidine, attributing extreme lethargy to the effects of the drug. One man, receiving cimetidine, complained of severe, central

TABLE 2. Healing of duodenal ulcers stratified by duration of dyspepsia

\begin{tabular}{|c|c|c|c|c|}
\hline & \multicolumn{2}{|c|}{ Ranitidine } & \multicolumn{2}{|c|}{ Cimetidine } \\
\hline & at 4 weeks & at 8 weeks & at 4 weeks & at 8 weeks \\
\hline Dyspepsia $<5$ yrs & $27 / 34(79 \%)$ & $33 / 34 \quad(97 \%)$ & $14 / 19(74 \%)$ & $15 / 19(79 \%)$ \\
\hline Dyspepsia $>5$ yrs & $15 / 19(79 \%)$ & $19 / 19(100 \%)$ & $23 / 31(74 \%)$ & $28 / 31(90 \%)$ \\
\hline
\end{tabular}


abdominal pain for 3 days. Subsequently he was found to have a raised blood sugar and glycosuria which were transient although the treatment medication was continued. Cholecystogram and ultrasound examination of the biliary tract were negative for gallstones. Endoscopy showed the duodenal ulcer to have healed satisfactorily. We believe that this was a mild bout of pancreatitis which resolved spontaneously. Although there have been a few case reports of acute pancreatitis in patients receiving cimetidine, the condition may not be drug related (Arnold, Doyle and Bell, 1978). Results of experimental studies in rats have shown conflicting results (Joffe and Lee, 1978; Szabo and Goldman, 1978). One patient on ranitidine and one on cimetidine felt general malaise, but in both cases the condition resolved while the patients continued taking the treatment agent.

\section{Laboratory investigations}

Data for assessing changes in laboratory measurements were analysed if measurements were made at Visit 1 (pretreatment) and at Visit 3 if this was 21-35 days after Visit 1 . There were no significant differences between the two groups for either visit for haemoglobin, platelet count, total white count, serum bilirubin, urea or aspartate transaminase levels and there were no significant changes between visits. In the cimetidine treatment group, the mean serum creatinine level rose from 93 to $102 \mathrm{mmol} /$ litre, whereas the level remained at $92 \mathrm{mmol} /$ litre in the ranitidine group. This observation has been made previously (Larsson et al., 1980) and is not thought to be clinically important. A slight fall in gamma glutamyl transaminase levels in the ranitidine group was matched by a slight rise in the cimetidine-treated groups. The difference was of statistical, but not clinical, significance.

\section{Discussion}

The present study confirms the effectiveness of ranitidine and cimetidine in the healing of duodenaf ulceration. The healing rate for ranitidine was simila? to that for cimetidine at 4 weeks, and at 8 weeks was significantly better $(P<0.05)$. Some early studies arg shown in Table 5 (Berstad et al., 1980; Gibinski et al, $\overrightarrow{;}$ 1981; Walt et al., 1981; Dobrilla et al., 1981; Peden $\overrightarrow{e_{0}}$ al., 1981). A previous report from this centres involving 50 patients, showed healing rates for ranitidine of $92 \%$ at 4 weeks and $100 \%$ at 8 weeks. compared with a healing rate of $29 \%$ for placeboe treated patients at 4 weeks (Lee, Costello an $\Phi_{8}$ Fielding, 1982). The healing rates for ranitidine are comparable to those reported for cimetidine (Gray $e \times 0$ al., 1977; Northfield \& Blackwood, 1977; Bardhan al., 1977). Clearly, ranitidine is at least as effective as. cimetidine in the short-term healing of duodenaf ulceration.

Previous reports have shown conflicting results i ulcer healing rates in men and women. Peden et $a \bar{R}$ (1981) reported that women were less likely than nee $\vec{b}$ to heal duodenal ulcers after 4 weeks' treatment witho $\mathrm{H}_{2}$ receptor antagonists. This trend had becoming apparent in more recent studies and selection factore may have been relevant. In contrast, no difference was noted between men and women in two studie? involving placebo and $\mathrm{H}_{2}$ blockers (Porro et al., 1981 क and low-dose antacid (Massarrat and Eisenmann? 1981) although, in this latter study, the trend was io favour of women. A favourable effect for women was found in a trial involving placebo, cimetidine and pirenzipine (Sonnenberg et al., 1981). At the high.

TABLE 5. Early trials of ranitidine in short-term healing of duodenal ulceration

\begin{tabular}{|c|c|c|c|c|c|c|}
\hline Author & Country & Number & $\begin{array}{c}\text { Ranitidine } \\
\text { dose } \\
\text { (mg/day) }\end{array}$ & $\begin{array}{l}\text { Length of } \\
\text { treatment } \\
\text { (weeks) }\end{array}$ & $\begin{array}{l}\text { Percentage } \\
\text { healed on } \\
\text { ranitidine }\end{array}$ & $\begin{array}{c}\text { Percentage } \\
\text { healed on } \\
\text { compared agent }\end{array}$ \\
\hline Berstad et al. (1980) & $\begin{array}{c}\text { Norway } \\
\text { (Multi-centre) }\end{array}$ & 50 & 200 & 4 & 92 & $\begin{array}{c}46 \\
\text { (placebo) }\end{array}$ \\
\hline Gibinski et al. (1981) & $\begin{array}{c}\text { Poland } \\
\text { (Multi-centre) }\end{array}$ & 168 & 300 & 3 & 82 & $\begin{array}{c}45 \\
\text { (placebo) }\end{array}$ \\
\hline Walt et al. (1981) & $\begin{array}{c}\text { U.K. } \\
\text { (Multi-centre) }\end{array}$ & 103 & 300 & 4 & 77 & $\stackrel{84}{\text { (cimetidine } 1 \mathrm{~g} / \text { day) }}$ \\
\hline Dobrilla et al. (1981) & $\begin{array}{c}\text { Italy } \\
\text { (Single-centre) }\end{array}$ & 40 & 160 & 4 & $83 \cdot 3$ & $\begin{array}{c}29 \cdot 4 \\
\text { (placebo) }\end{array}$ \\
\hline Peden et al. (1981) & $\begin{array}{c}\text { U.K. } \\
\text { (Single-centre) }\end{array}$ & 40 & 320 & 4 & 78 & $\begin{array}{c}45 \\
\text { (cimetidine } 800 \mathrm{mg} / \text { day }\end{array}$ \\
\hline $\begin{array}{l}\text { Lee et al. (1982) } \\
\text { (Present report) }\end{array}$ & $\begin{array}{c}\text { U.K. } \\
\text { (Single-centre) }\end{array}$ & 103 & 300 & 4 & 78 & $\stackrel{74}{\text { (cimetidine } 1 \mathrm{~g} / \text { day) }}$ \\
\hline & & & & 8 & 98 & (cimetidine $1 \mathrm{~g} /$ day) \\
\hline
\end{tabular}


healing rates for ranitidine and cimetidine reported in the present study, no difference in healing rates was found between men and women. Similarly, the present report shows no difference between smokers and non-smokers in contrast to several studies which have reported impaired healing rates in smokers (Massarrat and Eisenmann, 1981; Sonnenberg et al., 1981; Korman et al., 1981). At the healing rates relevant to currently used ulcer healing agents, very large numbers may be needed to detect differences.

Choice of agent, therefore, may depend on other factors such as compliance, unwanted effects and relapse rates after healing. Cimetidine has been shown to affect the hepatic metabolism of a number of drugs including antipyrine and aminopyrine (Staiger et al., 1980; Henry et al., 1980), warfarin and phenindione (Hetzel, Birkett and Miners, 1979), chlordiazepoxide and diazepam (Patwardham et al., 1980), phenytoin (Hetzel et al., 1981) and propranolol (Heagerty et al., 1981). In addition, cimetidine produces an elevation of serum prolactin levels after intravenous injection (Nelis and Van de Meene, 1980; Kleist et al., 1981). Ranitidine has been reported as showing more prolonged gastric acid suppression than cimetidine in a man with Zollinger-Ellison syndrome in whom gynaecomastia regressed and sexual activity improved when ranitidine was substituted for cimetidine (Mignon et al., 1980). The increased potency of ranitidine has been found useful in patients with life-threatening gastric hypersecretion resistant to cimetidine (Danilewitz, Tim and Hirschowitz, 1982). Like histamine, cimetidine has an imidazole ring and it may be that some of its unwanted effects are associated with its ring structure. Ranitidine has a nitrofuran ring and is a specific $\mathrm{H}_{2}$ receptor antagonist. Cimetidine has been in use for over 5 years and has an excellent tolerance and safety record. However, there are reservations about anti-androgenic activity and alterations in drug metabolism. These effects do not occur with ranitidine and there may be clinical situations where ranitidine is the preferred agent.

\section{Acknowledgments}

The assistance of the nursing and secretarial staff of the Gastroenterology Department is gratefully acknowledged. The Medical and Statistics Department of Glaxo Laboratories, Ware, U.K., cooperated in the organization of the trial.

\section{References}

ARNold, F., Doyle, P.J. \& Bell, G. (1978) Acute pancreatitis in a patient treated with cimetidine. Lancet, i, 382.

Bardhan, K.K., Saul, D.M., Balmforth, G.V., Maruyama, T., Duthie, H.L., FusSey, I.V., Heading, R.C., FetTes, M., Logan, R.F.A., HoldSWORTH, C.D., LANGMAN, M.J., DRONFIELD, M.W., LARK WORTHY, W., SMITH, P.M., EDWARDS, J.L., WYLIE, J.H.,
HAGgIE, S.J. \& HAWKINS, B.W. (1977) The effect of cimetidine on duodenal ulceration. In: Cimetidine (Ed. by Burland, W.L. \& Simkins, M.A.), p. 260, Excerpta Medica, Amsterdam.

Berstad, A., Kett, K., Aadland, E., Carlsen, E., Frislid, K., SAXHAUG, K. \& KruSe-Jensen, A. (1980) Treatment of duodenal ulcer with ranitidine, a new histamine $\mathrm{H}_{2}$ receptor antagonist. Scandinavian Journal of Gastroenterology, 15, 637.

DANILEWITZ, M., TIM, L.O. \& HIRSCHOWITZ, B. (1982) Ranitidine suppression of gastric hypersecretion resistant to cimetidine. New England Journal of Medicine, 306, 20.

Dobrilla, G., DE Pretis, G., Felder, M. \& Chilovi, F. (1981) Endoscopic double blind controlled trial of ranitidine $v s$ placebo in the short-term treatment of duodenal ulcer. Hepatogastroenterology, 28, 49 .

Gibinski, K., Nowak, A., Gabryelewicz, A., Szalaj, W., Hasik, J., Klincewicz, H., Pokora, J., Radwan, P.,r05 Kosecki, P. \& PACHLEWSKI, J. (1981) Multicentre double blind clinical trial on ranitidine for gastroduodenal ulcer. Hepatogastroenterology, 28, 216.

Gray, G.R., McKenzie, I., Smith, I.S., Crean, G.P. \& GillesPie, G. (1977) Oral cimetidine in severe duodenal ulceration. Lancet, $i$, 4.

Heagerty, A.M., Donovan, M.A., Castledon, C.M., Pohl, J.F., PATEL, L. \& HEDGes, A. (1981) Influence of cimetidine on pharmacokinetics of propranolol. British Medical Journal, 282 , 1917.

HenRy, D.A., Macdonald, I.A., Kitchingman, G., Bell, G.D. \& LANGMAN, M.J.S. (1980) Cimetidine and ranitidine: a comparison of effects on hepatic drug metabolism. British Medical Journal, 281, 775 .

Hetzel, D., Birkett, D. \& Miners, J. (1979) Cimetidine interaction with warfarin. Lancet, ii, 639 (Letter).

Hetzel, D.J., Bochner, F., Hallpine, J.F. \& Shearman, D.J.C. (1981) Cimetidine interaction with phenytoin. British Medical Journal, 282, 1512

JOFFE, S.N. \& LEE, F.D. (1978) Acute pancreatitis after cimetidine administration in experimental duodenal ulcers. Lancet, i, 383 (Letter)

Kleist, D. von., Graf, K.J., Dougherty, F.C. \& Hampel, K.E. (1981) Effects of cimetidine and ranitidine on gastric transmural potential difference and on prolactin secretion in man. Hepatogastroenterology, 28, 210.

Korman, M.G., Shaw, R.G., Hansky, J., Schmidt, G.T. \& Stern, A.I. (1981) Influence of smoking on healing rate of duodenal ulcer in response to cimetidine or high-dose antacid. Gastroenterology, 80,1451 .

LaRsSon, R., Bodemar, G., Kagedal, B. \& Whelan, A. (1980) The effects of cimetidine (Tagamet) on renal function in patients with renal failure. Acta medica Scandinavica, 208, 27.

LeE, F.I., Costello, F.T. \& Fielding, J.D. (1982) Ranitidine compared with placebo in the short-term healing of duodenal ulcer. In: The Clinical Use of Ranitidine. (Ed. by J.J. Misiewicz and K.G. Wormsley) p. 131. Medicine Publishing Foundation Symposium Series 5. Medicine Publishing Foundation, Oxford.

MassarRat, S. \& Eisenmann, A. (1981) Factors affecting the healing rate of duodenal and pyloric ulcers with low-dose antacid treatment. Gut, 22, 97.

Mignon, M., Vallot, B.J., Mayeur, T.H. \& Bonfils, S. (1980) Ranitidine and cimetidine in the Zollinger-Ellison syndrome. British Journal of Pharmacology, 10, 173.

NELIS, G.F. \& VAN DE MEENE, J.G.C. (1980) Comparative effect of cimetidine and ranitidine on prolactin secretion. Postgraduate Medical Journal, 56, 478.

NORTHFIELD, T.C. \& BLACK WOOD, W.S. (1977) Controlled clinical trial of cimetidine for duodenal ulcer. In: Cimetidine (Ed. by Burland, W.L. \& Simkins, M.A.), p. 272. Excerpta Medica, Amsterdam.

Patwardham, R.V., Yarborough, G.W., Desmond, P.V., JohnSON, R.F., SCHENKER, S. \& SPEEG, K.V. (1980) Cimetidine spares the glucuronidation of lorazepam and oxasepam. Gastroentero$\log y, 79,912$. 
Peden, N.R., Boyd, E.J.S., SAunders, J.H.B. \& Wormsley, K.G. (1981) Ranitidine in the treatment of duodenal ulceration. Scandinavian Journal of Gastroenterology, 16, 325.

PEDEN, N.R., BOYD, E.J.S. \& WORMSLEY, K.G. (1981) Women and duodenal ulcer. British Medical Journal, 282, 866 (Letter).

Porro, G.B., Prada, A., Petrillo, M. \& Lazzaroni, M. (1981) Women and duodenal ulcer. British Medical Journal, 283, 235 (Letter).

SATTERTHWAITE, F.E. (1946) Biometrics Bulletin, 2, 100.

SNEDECOR, G.W. \& COCHRAN, W.G. (1967) Statistical Methods, 6th edn, p. 253. Iowa State University Press, Ames, Iowa.

Sonnenberg, A., Muller-Lissner, S.A., Vogel, E., SChmid, P. Gonvers, J.J., Peter, P., STrohmeyer, G. \& Blum, A.L. (1981)
Predictors of duodenal ulcer healing and relapse. Gastroentero $\log y, 81,1061$.

Staiger, C., Simon, B., Walter, B. \& Kather, H. (1980) Influe ences of ranitidine on antipyrine pharmacokinetics in healthy. volunteers. Digestive Diseases \& Sciences, 25, 894.

SzaBo, S. \& Goldman, H. (1978) Cimetidine and pancreatitis lessons from animal experiments. Lancet, ii, 266 (Letter).

Walt, R.P., Trotman, I.F., Frost, R., Golding, P.L., ShePherdo T.H., Rawlings, J., Hunt, R.H., Colin-Jones, D., Milton $\frac{\text { - }}{\text { J }}$ THOMPSON, G.J. \& MisiewICZ, J.J. (1981) Comparison of twiceD daily ranitidine with standard cimetidine treatment of duodenaf ulcer. Gut, 22, 319.

(Accepted 13 August 1982) 